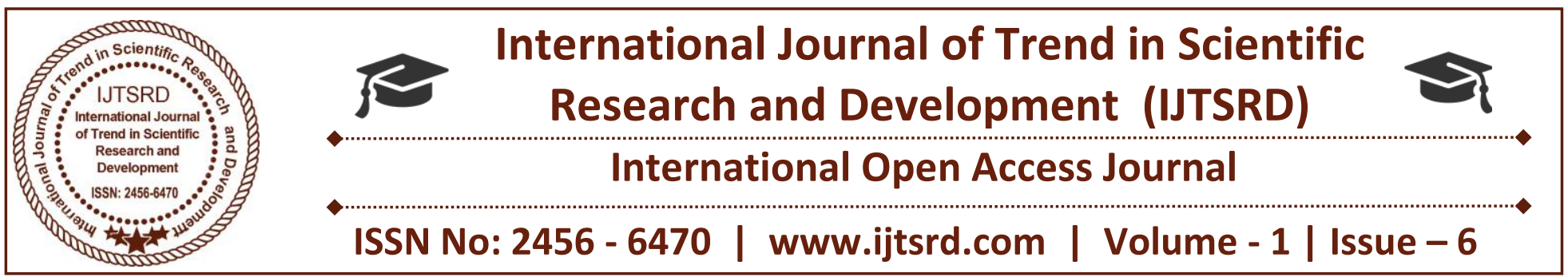

\title{
Experimental Investigations on by using Quarry Dust Durability Properties of Concrete
}

\author{
G.Anil \\ Department of Civil Engineering, \\ Chirala Engineering College, \\ Chirala, Andhra Pradesh, India
}

\author{
A.Pavani \\ Department of Civil Engineering, \\ Chirala Engineering College, \\ Chirala, Andhra Pradesh, India
}

\section{ABSTRACT}

For a long time concrete was considered to be very durable material requiring. We build concrete Structures in highly polluted urban and industrial areas. Aggressive marine environments harmful Subsoil water in area and many other hostile conditions where other materials of construction are found is non-durable. Leaving waste materials into environment directly can cause environmental problems. Quarry dust a waste from the quarry processing units accounts $30 \%$ of the final product from Quarry industry Therefore this waste can be used to produce new product or can be used as admixtures. So That the natural resources are use deficiently and hence environmental waste can be reduced. Here quarry dust is used for partial replacement of cement in concrete for study of physical and mechanical Properties of concrete.

The present project deals with the study of durably conditions of concrete made with partial replacement of cement with quarry dust proportions of $0 \%, 10 \%$, $20 \%$ and $30 \%$ by weight of cement. Immersion test of sulphuric acid and hydrochloric acid are conducted at $5 \%$ by volume of water.

Keywords: Concrete, Quarry dust, Fly Ash, Fine Aggregate, Compressive Strength, sulphuric acid and hydrochloric acid

\section{INTRODUCTION}

For quite a while cement was thought to be exceptionally strong material requiring. We assemble solid structures in profoundly dirtied urban and modern ranges, forceful marine situations, destructive sub-soil water in territory and numerous other antagonistic conditions where different materials of development are found be non-durable. Since the utilization of solid as of late have spread to exceptionally cruel and unfriendly conditions, the prior impression that solid is an extremely strong material is being debilitated, especially because of untimely disappointments of number of structures.

In the past just quality of cement was considered in the solid blend outline strategy accepting quality of solid in all plaguing variable for all other attractive properties of solid including strength. In the late correction of IS 456 of 2000, one of the points discussed, deliberated and revised is the durability aspects of concrete, in line with codes of practice of other countries, which have better experiences in dealing with durability of concrete structures. One of the main reasons for deterioration of concrete in the past is that too much emphasis is placed on concrete compressive strength. In actuality progression in solid innovation has been for the most part on the quality of cement. It is presently perceived that quality of cement alone is not adequate, the level of cruelty of nature condition to which cement is uncovered over its whole life is just as vital. Accordingly, both quality and strength must be considered expressly at the 
configuration state. It is fascinating to consider yet another perspective point with respect to quality and toughness relationship. Strength of cement is its

Imperviousness to disintegrating organizations to which the solid may be uncovered amid its administration life. At the point when one manages the sturdiness parts of cement, the concoction assault, which brings about loss of weight, splitting of cement and the subsequent decay of cement, turns into an essential piece of examination. Conventional Portland bond concrete for the most part does not have great imperviousness to corrosive assault. The expansion of FA enhances the small scale basic properties of solid like porosity, penetrability and sorptivity. The decrease of porosity and penetrability suggests the change in compound

Assault and consumption resistance the exploratory examination of this perspective is to discover compressive quality and solidness of cement by fractional supplanting of bond with quarry dust. Sturdiness is a critical building property of cement, which decides the administration life of solid structures essentially. Because of the associations of cement with outer impacts, the mechanical and physical properties of solid may be undermined and lost. ACI Committee Report 201(2001) has characterized concoction assaults into a few sorts that incorporate acidic assault, soluble base assault, carbonation, chloride assault, and draining and sulfate assault. Acidic assault for the most part starts from mechanical procedures, yet it can even be because of urban movement. Indeed, even common presentation conditions may bring about corrosive assaults. Free acids in normal waters are uncommon. Special cases are carbonic waters and sulfurous and sulfuric acids in peat waters. Soils may contain numinous acids. A few natural and inorganic acids may happen in shallow locales of ocean water as a result of bacteriological action. Noteworthy amounts of free acids in plants and production lines may be found. In these cases, the centralization of corrosive, which interacts with solid structures, may reach to high esteem. The level of aggressivity of a corrosive is subject to the substance character of anions present. The quality of corrosive, its separation degree in arrangements and, primarily, the calcium's solvency salts shaped are subject to the concoction character of anion. The acidic assault is influenced by the procedures of deterioration and draining of the constituent of bond framework
The objective of the present project work is to study the behavior of concrete in partial replacement for cement with quarry dust in proportions. It includes a brief description of the materials used in the concrete mix, mix proportions, the preparation of the test specimens and the parameters studied. In order to achieve the stated objectives, this study is carried out in different stages. In the initial stage, all the materials and equipment needed must be gathered or checked for availability. Once the characteristics of the materials selected have been studied through appropriate tests, the applicable standards of specification are referred. The properties of hardened concrete are important as it is retained for the remainder of the concrete life. In general, the important properties of hardened concrete are strength and durability. An experimental program is held to measure strength of hardened concrete.

\subsection{ORDINARY PORTLAND CEMENT:}

Portland bond is the most normally utilized kind of concrete as a part of the world today. Portland bond can be found in both cement and mortar, where it goes about as coupling operators. On a concoction level, Portland bond is a fine powder included at least $66 \%$ calcium silicate, with the rest of being a blend of aluminum, and iron. Portland concrete is a pressure driven material, which requires the expansion of water so as to frame exothermic bonds, and is not solvent in water.

FInitially outlined as a concrete which would set gradually, sufficiently permitting time for it to be legitimately laid, and a water safe bond which could be utilized as a part of development applications where water would interact with the bond, Portland concrete was initially protected in 1824 by an English man, Joseph Asp clamor, yet the blend which turned out to be genuinely fruitful, and which is still utilized today, was composed by his child, William Asp commotion in around 1843.

\subsection{PORTLAND CEMENT APPLICATIONS:}

Portland cement is most often used in concrete and mortar. Concrete is made by combining water, sand, gravel, and cement, whereas mortars are made by combining cement with water and sand only. Concrete is much stronger than mortar, and is used in most modern buildings as a durable and strong construction material capable of bearing great loads. Mortar is used 
to bind other substances together, such as the bricks in a house.

\subsection{PORTLAND CEMENT STRENGTH:}

Portland cement usually takes several hours to set, and will harden in a matter of weeks. Cement is a somewhat curious material in that it continues to harden over time as long as there is water available for the components of the cement to form bonds with. One week old Portland cement has strength of around $23 \mathrm{MPa}$, whereas three month old cement has strength of $41 \mathrm{MPa}$. These numbers apply to standard Portland cement which has not had any additives added to it. Various treatments and additives can make cement set and harden at different rates, and various types of Portland cement also posses different properties which effect the rate of setting and hardening.

\section{Table 1 Chemical Composition of Portland cement}

\begin{tabular}{|l|l|l|}
\hline $\begin{array}{l}\text { Oxide } \\
\text { Composition }\end{array}$ & Abbreviation & $\begin{array}{l}\text { Percent } \\
\text { content }\end{array}$ \\
\hline Lime & $\mathrm{CaO}$ & $60-67$ \\
\hline Silica & $\mathrm{SiO}_{2}$ & $17-25$ \\
\hline Alumina & $\mathrm{Al}_{2} \mathrm{O}_{3}$ & $3.0-8.0$ \\
\hline Iron Oxide & $\mathrm{Fe}_{2} \mathrm{O}_{3}$ & $0.5-2.0$ \\
\hline Sulphate & $\mathrm{SO}_{3}$ & $1.3-3.0$ \\
\hline Magnesia & $\mathrm{MgO}_{2} \mathrm{O}$ & $0.1-4.0$ \\
\hline Alkalies & $\mathrm{K}_{2} \mathrm{O}, \mathrm{Na}_{2} \mathrm{O}$ & $0.4-1.3$ \\
\hline
\end{tabular}

Portland concrete comprises of the accompanying concoction mixes:

a) Tricalcium silicate $3 \mathrm{CaO} . \mathrm{SiO} 2$ (C3S) $40 \%$

b) Dicalcium silicate $2 \mathrm{CaO} . \mathrm{SiO} 2$ (C2S) $30 \%$

c) Tricalcium aluminate $3 \mathrm{CaO} . \mathrm{Al} 2 \mathrm{O} 3$ (C3A) $11 \%$

d) Tetracalcium aluminate 4CaO.A12O3.Fe2O3 (C3AF) $11 \%$.

\section{DURABILTY OF CONCRETE}

\subsection{Tests on durability}

\subsubsection{Mass loss}

The solid 3D shapes of $100 \mathrm{~mm} * 100 \mathrm{~mm} * 100 \mathrm{~mm}$ size were thrown for discovering the mass misfortune because of the corrosive assault. The readied 3D squares were cured in water for 28 days after which they were drenched in $5 \% \mathrm{H} 2 \mathrm{SO} 4$ and $5 \% \mathrm{HCl}$ arrangements. The introductory mass and the mass of solid examples after the inundation time of 3 days, 7 days and 28 days and were measured for discovering the mass misfortune because of the weakening of solid examples. The normal estimation of three examples was considered for evaluation.

\subsubsection{Strength deterioration factor (SDF)}

The deterioration of concrete cube specimens was investigated by measuring the strength deterioration factor expressed in percentage and it was calculated by using the equation [11-12]. SDF $=\left[\frac{\mathrm{fcw}-\mathrm{fca}}{\mathrm{fcw}}\right] * 100$

Where, fcw is the average compressive strength of concrete cubes cured in water and fca is the average compressive strength of cubes immersed in acid solutions. The compressive strength test was carried out for each specimen in both the solutions after 7 days and 28 days of immersion period. In each test period, the average value specimens were tested and reported.

\subsection{Study of weight loss and strength loss of concrete}

Concrete can be subjected to attack by various mineral acids, which include sulphuric and hydrochloric acids. In natural ground water, only sulphuric acid is likely to be found as a result of the oxidation of sulphide minerals such as pyrites and marc site, a process which is catalyzed by the presence of the aerobic bacterium, thiobacillus ferrooxidans. When concrete is in contact with such acidic waters, the calcium hydroxide reacts with the sulfuric acid to form gypsum, which can be readily washed away. Sulphuric acid is also one of the main acidifying agents of acid rain. Much higher concentrations can occur in industrial environments. The most common forms of such attack are random spilling, unscheduled washing down and dumping of chemical waste from industrial processes. Another source of severe sulphuric acid attack, which is very common worldwide, is that which generates by bacteria in concrete sewage systems. The anaerobic bacteria generates hydrogen sulfate gas which can dissolve in water condensed on the walls of the concrete conduits, pipes, and manholes above the sewage line level where aerobic bacteria can produce sulphuric acid. (Ref: The confused world of sulfate attack on concrete: Adam Neville, 2004, cement and concrete research.)

\section{3 Impact of water bond proportion on strength of cement}


The effect of water/bond proportion is all that much noteworthy on cement. The increment in water amount prompts the vicinity of more water this will end up being a contributory element for volume change in this manner higher water/concrete proportion prompts higher porousness and quality lessening because of high volume of water. The utilization of higher water/concrete proportion prompts back to back and recurrent problematic activities. The impacts are of volume change, which bring about breaks, splits causes crumbling of the structure in the end structure will prompts disintegration of cement. Subsequently extensive water/bond proportion is constantly expected to deliver more solid, thick and impermeable cement. The effect of water/bond proportion is incredibly obvious and identifiable in the miniaturized scale structures of the solid. The impact of chloride particles on the solid made of low water/bond proportion is all that much slower than in the solid with higher water/concrete proportion. The response is 10-50 times slower than that of higher water/bond proportion concrete. It has as of now been demonstrated that low water/bond proportion cements are less delicate to carbonation influence, as opposed to higher water/concrete proportion on cement. Strength of the solid may be comprehended as its capacity to oppose weathering, scraped area, compound assault or any procedure of crumbling, if this solid is said to be sturdy it has hold its unique structure, quality and serviceability when presented to its workplaces. Out of the considerable number of variables impact the solidness of solid synthetic assault is a fascinating element which is in charge of decay of structures. When we concentrate on the synthetic activity on solid we should need to study sulfate assault, soluble base - total response, carbonation, corrosive assault and impact of ocean water

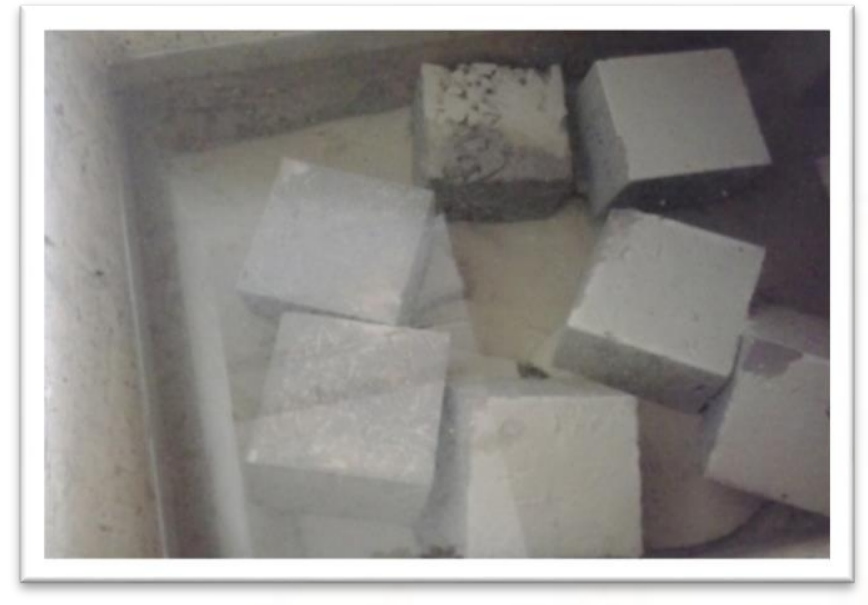

Fig.1 Cubes immersed in $\mathrm{H}_{2} \mathrm{SO}_{4}$

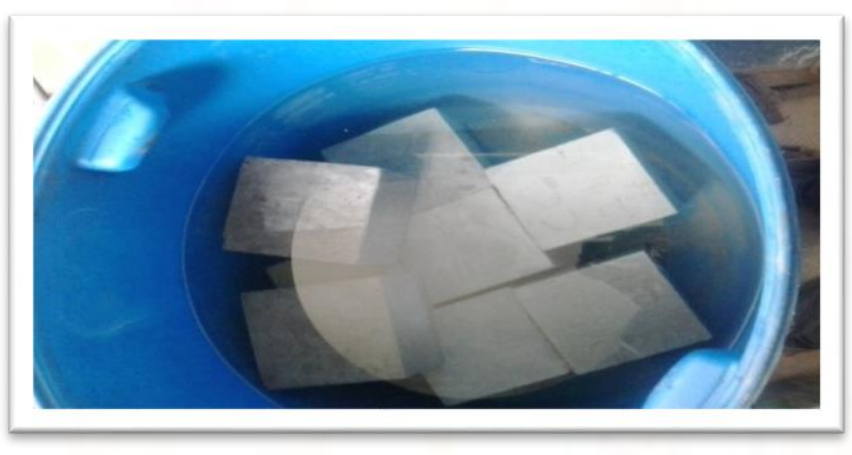

Fig.2 Cubes immersed in HCL

\subsection{Experimental Procedure}

The aim of the present study is to identify and estimate the effect of $\mathrm{H} 2 \mathrm{SO} 4, \mathrm{HCl}$ on concrete made up of partial replacement of cement with quarry dust. The studies conducted on the durability of the concrete against the attack of H2 So4, HCL.

For M20 grade concrete we prepared 5 cubes for $0 \%$ quarry dust replacement for cement. Similarly, we prepared for $5 \%, 10 \%, 15 \%, 20 \%, 25 \%, 30 \%$ and $35 \%$ replacement of cement with quarry dust.

For M30 grade concrete we prepared 5 cubes for 0\% quarry dust replacement for cement. Similarly, we prepared for $5 \%, 10 \%, 15 \%, 20 \%, 25 \%, 30 \%$ and $35 \%$ replacement of cement with quarry dust.

For M40 grade concrete we prepared 5 cubes for 0\% quarry dust replacement for cement. Similarly, we prepared for $5 \%, 10 \%, 15 \%, 20 \%, 25 \%, 30 \%$ and $35 \%$ replacement of cement with quarry dust.

A total of 2 sets of cubes of each grade of M20, M30, and M40 of size $100 \mathrm{~mm} \times 100 \mathrm{~mm} \times 100 \mathrm{~mm}$ are casted. Each set consist of 120 cubes are cured in water. After 28 days of curing in water 120 cubes is 
International Journal of Trend in Scientific Research and Development (IJTSRD) ISSN: 2456-6470

immersed in 5\% concentrated $\mathrm{H} 2 \mathrm{SO} 4$ and another 120 cubes are immersed in 5\% concentrated HCL. The percentage weight loss, compressive strength loss is taken for a set of cubes at 7days and 28 days for both HCL and H2SO4.

\section{RESULTS}

Table 3.1 M20 average \% of mass loss after immersion in $\mathrm{H}_{2} \mathrm{SO}_{4}$

\begin{tabular}{|l|l|l|l|l|l|}
\hline Mix.no & $\begin{array}{l}\text { \% of } \\
\text { Cement }\end{array}$ & $\begin{array}{l}\text { \% of } \\
\text { Quarry } \\
\text { dust }\end{array}$ & $\begin{array}{l}\mathbf{3} \\
\text { Days } \\
\text { avg } \% \\
\text { of } \\
\text { weight } \\
\text { loss }\end{array}$ & $\begin{array}{l}\text { 7 } \\
\text { Days } \\
\text { avg } \\
\text { of } \\
\text { weight } \\
\text { loss }\end{array}$ & $\begin{array}{l}\text { 28 } \\
\text { Days } \\
\text { avg \% } \\
\text { of } \\
\text { weight } \\
\text { loss }\end{array}$ \\
\hline $\mathbf{A}_{\mathbf{2}} \mathbf{Q}_{\mathbf{0}}$ & 100 & 0 & 3.83 & 5.45 & 10.52 \\
\hline $\mathbf{A}_{\mathbf{2}} \mathbf{Q}_{\mathbf{1}}$ & 95 & 5 & 2.16 & 13.03 & 9.91 \\
\hline $\mathbf{A}_{\mathbf{2}} \mathbf{Q}_{\mathbf{2}}$ & 90 & 10 & 4.13 & 10.72 & 10.72 \\
\hline $\mathbf{A}_{\mathbf{2}} \mathbf{Q}_{\mathbf{3}}$ & 85 & 15 & 3.57 & 18.81 & 11.75 \\
\hline $\mathbf{A}_{\mathbf{2}} \mathbf{Q}_{\mathbf{4}}$ & 80 & 20 & 3.74 & 12.71 & 11.04 \\
\hline $\mathbf{A}_{\mathbf{2}} \mathbf{Q}_{\mathbf{5}}$ & 75 & 25 & 2.26 & 13.90 & 11.26 \\
\hline $\mathbf{A}_{\mathbf{2}} \mathbf{Q}_{\mathbf{6}}$ & 70 & 30 & 3.38 & 15.07 & 11.38 \\
\hline $\mathbf{A}_{\mathbf{2}} \mathbf{Q}_{\mathbf{7}}$ & 65 & 35 & 3.68 & 13.07 & 11.30 \\
\hline
\end{tabular}

Table 3.2 M30 average \% of mass loss after immersion in $\mathrm{H}_{2} \mathrm{SO}_{4}$

\begin{tabular}{|l|l|l|l|l|l|}
\hline Mix.no & $\begin{array}{l}\text { \% of } \\
\text { Cement }\end{array}$ & $\begin{array}{l}\text { \% of } \\
\text { Quarry } \\
\text { dust }\end{array}$ & $\begin{array}{l}\text { 3 Days } \\
\text { avg \% } \\
\text { of } \\
\text { weight } \\
\text { loss }\end{array}$ & $\begin{array}{l}\text { 7 Days } \\
\text { avg } \% \\
\text { of } \\
\text { weight } \\
\text { loss }\end{array}$ & $\begin{array}{l}\mathbf{2 8} \\
\text { Days } \\
\text { avg \% } \\
\text { of } \\
\text { weight } \\
\text { loss }\end{array}$ \\
\hline $\mathbf{A}_{\mathbf{3}} \mathbf{Q}_{\mathbf{0}}$ & 100 & 0 & 1.12 & 4.755 & 9.6 \\
\hline $\mathbf{A}_{\mathbf{3}} \mathbf{Q}_{\mathbf{1}}$ & 95 & 5 & 3.74 & 8.63 & 14.00 \\
\hline $\mathbf{A}_{\mathbf{3}} \mathbf{Q}_{\mathbf{2}}$ & 90 & 10 & 2.183 & 3.90 & 11.70 \\
\hline $\mathbf{A}_{\mathbf{3}} \mathbf{Q}_{\mathbf{3}}$ & 85 & 15 & 3.41 & 8.20 & 12.69 \\
\hline $\mathbf{A}_{\mathbf{3}} \mathbf{Q}_{\mathbf{4}}$ & 80 & 20 & 2.183 & 3.19 & 11.81 \\
\hline $\mathbf{A}_{\mathbf{3}} \mathbf{Q}_{\mathbf{5}}$ & 75 & 25 & 1.54 & 2.17 & 11.32 \\
\hline $\mathbf{A}_{\mathbf{3}} \mathbf{Q}_{\mathbf{6}}$ & 70 & 30 & 2.183 & 3.90 & 11.93 \\
\hline $\mathbf{A}_{\mathbf{3}} \mathbf{Q}_{\mathbf{7}}$ & 65 & 35 & 1.84 & 2.07 & 11.71 \\
\hline & & & & & \\
\hline
\end{tabular}

Table 3.3 M40 average \% of mass loss after immersion in $\mathrm{H}_{2} \mathrm{SO}_{4}$

\begin{tabular}{|l|l|l|l|l|l|}
\hline Mix.no & $\begin{array}{l}\text { \% of } \\
\text { Cement }\end{array}$ & $\begin{array}{l}\text { \% of } \\
\text { Quarry } \\
\text { dust }\end{array}$ & $\begin{array}{l}\text { 3 Days } \\
\text { avg } \\
\text { of } \\
\text { weight } \\
\text { loss }\end{array}$ & $\begin{array}{l}\text { 7 Days } \\
\text { avg \% } \\
\text { of } \\
\text { weight } \\
\text { loss }\end{array}$ & $\begin{array}{l}\mathbf{2 8} \\
\text { Days } \\
\text { avg \% } \\
\text { of } \\
\text { weight } \\
\text { loss }\end{array}$ \\
\hline $\mathbf{A}_{\mathbf{4}} \mathbf{Q}_{\mathbf{0}}$ & 100 & 0 & 1.98 & 2.61 & 9.97 \\
\hline $\mathbf{A}_{\mathbf{4}} \mathbf{Q}_{\mathbf{1}}$ & 95 & 5 & 1.74 & 2.29 & 11.61 \\
\hline $\mathbf{A}_{\mathbf{4}} \mathbf{Q}_{\mathbf{2}}$ & 90 & 10 & 2.01 & 2.86 & 11.23 \\
\hline $\mathbf{A}_{\mathbf{4}} \mathbf{Q}_{\mathbf{3}}$ & 85 & 15 & 2.5 & 9.69 & 12.42 \\
\hline $\mathbf{A}_{\mathbf{4}} \mathbf{Q}_{\mathbf{4}}$ & 80 & 20 & 2.12 & 2.86 & 11.46 \\
\hline $\mathbf{A}_{\mathbf{4}} \mathbf{Q}_{\mathbf{5}}$ & 75 & 25 & 1.96 & 5.11 & 12.69 \\
\hline $\mathbf{A}_{\mathbf{4}} \mathbf{Q}_{\mathbf{6}}$ & 70 & 30 & 2.22 & 2.86 & 11.69 \\
\hline $\mathbf{A}_{\mathbf{4}} \mathbf{Q}_{\mathbf{7}}$ & 65 & 35 & 2.37 & 3.42 & 11.04 \\
\hline & & & & & \\
\hline
\end{tabular}

Table $3.7 \mathrm{M20}$ average $\%$ of 7 days Strength deterioration when immersed in $\mathrm{H}_{2} \mathrm{SO}_{4}$

\begin{tabular}{|c|c|c|c|c|c|}
\hline $\begin{array}{l}\text { Mix. } \\
\text { No }\end{array}$ & 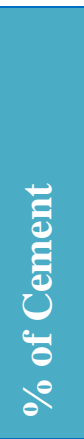 & 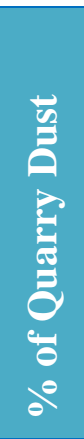 & $\begin{array}{l}\text { 7days } \\
\text { Avg. } \\
\text { Compr } \\
\text { essive } \\
\text { Strengt } \\
\text { h } \\
\text { before } \\
\text { immers } \\
\text { ion }\end{array}$ & $\begin{array}{l}\text { 7days Avg. } \\
\text { Compressi } \\
\text { ve } \\
\text { Strength } \\
\text { after } \\
\text { immersion } \\
\left(\mathrm{H}_{2} \mathrm{SO}_{4}\right)\end{array}$ & $\begin{array}{l}\text { Averag } \\
\text { e \% of } \\
\text { Strengt } \\
\text { h } \\
\text { deterior } \\
\text { ation }\end{array}$ \\
\hline $\mathbf{A}_{2} \mathbf{Q}_{0}$ & 100 & 0 & 18.45 & 14.95 & 18.97 \\
\hline $\mathbf{A}_{2} \mathbf{Q}_{1}$ & 95 & 5 & 18.39 & 13.03 & 29.14 \\
\hline $\mathbf{A}_{2} \mathbf{Q}_{2}$ & 90 & 10 & 18.33 & 12.9 & 29.62 \\
\hline $\mathbf{A}_{2} \mathbf{Q}_{3}$ & 85 & 15 & 19.47 & 14 & 28.09 \\
\hline $\mathbf{A}_{2} \mathbf{Q}_{4}$ & 80 & 20 & 20.65 & 14.5 & 29.78 \\
\hline $\mathbf{A}_{2} \mathbf{Q}_{5}$ & 75 & 25 & 21.33 & 14.85 & 30.37 \\
\hline $\mathbf{A}_{2} \mathbf{Q}_{6}$ & 70 & 30 & 13.42 & 12.6 & 23.66 \\
\hline $\mathbf{A}_{2} \mathbf{Q}_{7}$ & 65 & 35 & 15.37 & 11 & 28.43 \\
\hline
\end{tabular}




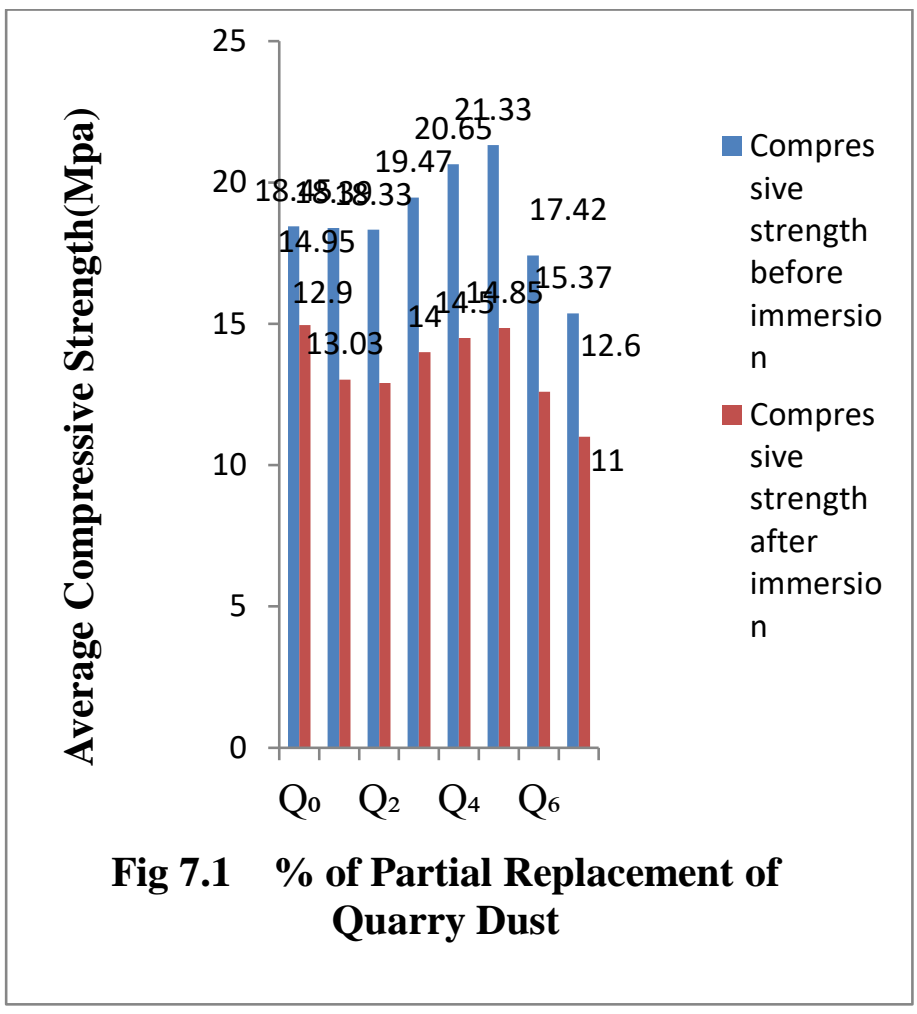

\section{CONCLUSION}

1. From the experiments conducted, replacement of quarry dust can be made for cement, as cement content in concrete can be optimized.

2. No change of W/C ratio was observed by replacement of cement with quarry dust, as quarry dust is a waste material; W/C ratio was compared with cement concrete.

3. At 5\% replacement of cement with quarry dust no change mechanical properties of concrete are observed in comparison with cement concrete.

4. From $10 \%$ to $25 \%$ replacement of quarry dust with cement the strength properties are increased linearly and from $30 \%$ to $35 \%$ of replacement of quarry dust, decrease in strength of concrete was observed

\section{Strength deterioration:}

1. It was observed that strength loss of specimens is high after immersion in $5 \% \mathrm{H}_{2} \mathrm{SO}_{4}$ of volume of water.

2. It is found that strength loss is more for A40 grade concrete when compared with A30, A20 grades concrete, by the immesion test of concrete cubes in $5 \%$ of $\mathrm{H}_{2} \mathrm{SO}_{4}$ solution of volume of water.

3. It is noted that sulphuric acid reacts with calcium present in cement and gives paste of gypsum which reduces the concrete strength.
4. It was observed that speciAens immersed in 5\% HCL of voluAe of water does not effect the strength for 7 days.

\section{Weight loss:}

1. 1.It is found that weight loss of concrete cubes is more in the immersion of $5 \%$ of $\mathrm{H}_{2} \mathrm{SO}_{4}$ in volume of water when compared with $5 \%$ of $\mathrm{HCL}$ in volume of water.

2. 2.In $5 \%$ of $\mathrm{H}_{2} \mathrm{SO}_{4}$ solution the weight loss for $\mathrm{A} 20$ grade is more when compared with A30 and A40 for 3 days and 7 days.

3. 3.It is observed that their is no effect on specimens for 3 days and 7 days when immersed in 5\% HCL in volume of water.

4. 4.Their is an shall weight loss in specimens for 28 days when immersed in 5\% HCL solution in volume of water.

\section{REFERENCES}

1) Valeria Corinaldesi, GiacoAo Aoriconi, and Tarun R. Naik. 2005. Characterization of Arable powder for its use in Aortar and concrete. NAET/ACI international Symposium on Sustainable Development of Cement and Concrete, October 57, Toronto, Canada.

2) Ilangovana, R. Aahendrana, N. and NagaAanib, 2008. "Strength and durability properties of concrete containing quarry rock dust as fine aggregates", ARPN Journal of Engineering and Applied Science, Vol.3 (5), pp 2022.

3) IS: 2386-1963 Part I to VII. Indian standard Methods for test for aggregate for concrete. Bureau of Indian standards, New Delhi.

4) IS: 516-1959, Indian Standard Methods of test for strength of concrete. Bureau of Indian standards, New Delhi.

5) IS: 10262-2009 and SP: 23:1982 Recommended Guidelines for concrete Aix. Bureau of Indian standards, New Delhi.

6) Nagaraj T.S. and Zahida Banu 1992. Efficient utilization of rock dust and pebbles as aggregates in Portland cement concrete. The Indian concrete journal.

7) IS:8112-1989, Specifications for 43 grade ordinary Portland cement, Bureau of Indian standards, New Delhi.

8) A.Sharul HaAAed and A.S.S.Sekhar, "properties of green concrete containing quarry rock dust and Aarble sludge powder as fine aggregate", ARPN journal 
International Journal of Trend in Scientific Research and Development (IJTSRD) ISSN: 2456-6470

of engineering and applied sciences vol.4, June 2009.

9) Prof.. jayeshkuAar Pitroda, Dr.L.B.ZALA, Dr.F.S.UAriagr (2012), “experiAental investigations on partial replacement of cement with fly ash in design Aix concrete". International journal of advanced engineering technology, IJAET/Vol.III/Issue IV/ oct-dec., 2012/126-129.

10) Ilangovan R. and NagaAani K. 2006 Application of quarry rock dust as fine aggregate in concrete construction. National journal on construction AanageAent, NICAAR. Pune.

11) Sahu A.K., Sunil KuAar and SacheA A.K. 2003 Quarry stone waste as fine aggregate for concrete. The Indian concrete journal. Pp 845-848.

12) Prakash Rao D.S. and Gridhar v. 2004 Investigation on concrete with stone crusher as fine aggregate.

13) IS: 12269-1987 Specification for 53 grade ordinary Portland cement.

14) Ali Ergun, Effects of usage of diatoAite and waste Aarble powder as partial replacement of cement on the Aechanical properties of concrete. Construction and Building Aaterials 2011; 25:806-812.

15) Felix F. Udoeyo, Properties of sawdust as partial replacement of cement.J.Aater.Civ.Eng.2002; 14:173-172.

16) Felix F.Udoeyo, ExaAined properties of Aaizecob Ash as filler in concrete as partial replacement of cement.

17) Noor-ul AAen, The use of bagasse ash in concrete and its impact on the strength and chloride resistivity.

18) Roz-Ud-Din Nasser and Parviz Soroushian, The strength of recycled aggregate concrete containing Ailled glass as partial replacement for cement. Construction and Building Aaterials.2012; 29:368-373.

19) Roz-Ud-Din Nasser and Parviz Soroushian, the durability of recycled aggregate. Concrete containing Ailled glass as partial replacement for cement. Construction and Building Aaterials.2012; 29:368-373.

20) Basher Taha, Conducted properties of concrete contains Aixed colour waste recycled glass as cement replacement.J.Aater.Civ.Eng.2009; 21:709-721.

21) Augustine Uche Elinwa and Yakubu Abba AahAud, Ash froA tiAber waste as partial replacement of cement.Cement\&Concrete CoAposites 2002 ;24: 219-222.
22) Auhd fadhil, Workability and CoApressive strength of ductile self coApacting concrete (DSCC) with various cement replacement Aaterials

23) Chandana Sukesh,Bala Krishna KatakaA,P saha and K.shyaA ChaAberlin, A study of sustainable industrial waste Aaterials as partial replacement of cement.

24) Siva KuAar Naganathan,Hashim Abdul Razak and Siti Nadzriah Abdul HuAid, Properties of controlled low strength Aaterial Aade using industrial waste incineration bottom ash and quarry dust.Aaterial and Design .2012;33:56-63.

25) H.A.F.Dehwah, the mechanical properties of selfcompacting concrete incorporating quarry dust powder, silica fuAe or fly ash

26) Gabriele Fava,Aaria Letizia Ruello and Valeria Corinaldesi, studied the use of paper mill sludge ash as supplementary cementitious Aaterial.J.Aater.Civ.Eng.2011;23:772-772.

27) Xiaoyan huang,Ravi ReAade and Victor C.Li,F.ASCE,The behavior of study of developing green engineering cementations coAposites (ECC) using iron ore tailings powder as

cement

replacement.J.Aater.Civ.Eng.2013;25:923-931.

28) Xiaolu Guo, the utilization of steel slag powder as a coAbined adAixture with ground granulated blast furnace slag in cement based Aaterials

29) Pailyn Thongsanitgarn, hydration and coApressive strength of blended cement containing fly ash and liAestone as cement replacement

30) Basher Taha and Ghassan Nounu,Utilizing waste recycled glass as cement replacement in concrete.

31) Joo-Hwa Tay, ash froA oil palA waste as concrete Aaterial as partial replacement of cement

32) S.A. Abukersh, used recycled aggregate concrete produced with red granite dust as a partial cement replacement. 